"Using DuPont analysis to assess the financial performance of the top 3 JSE listed companies in the food industry"

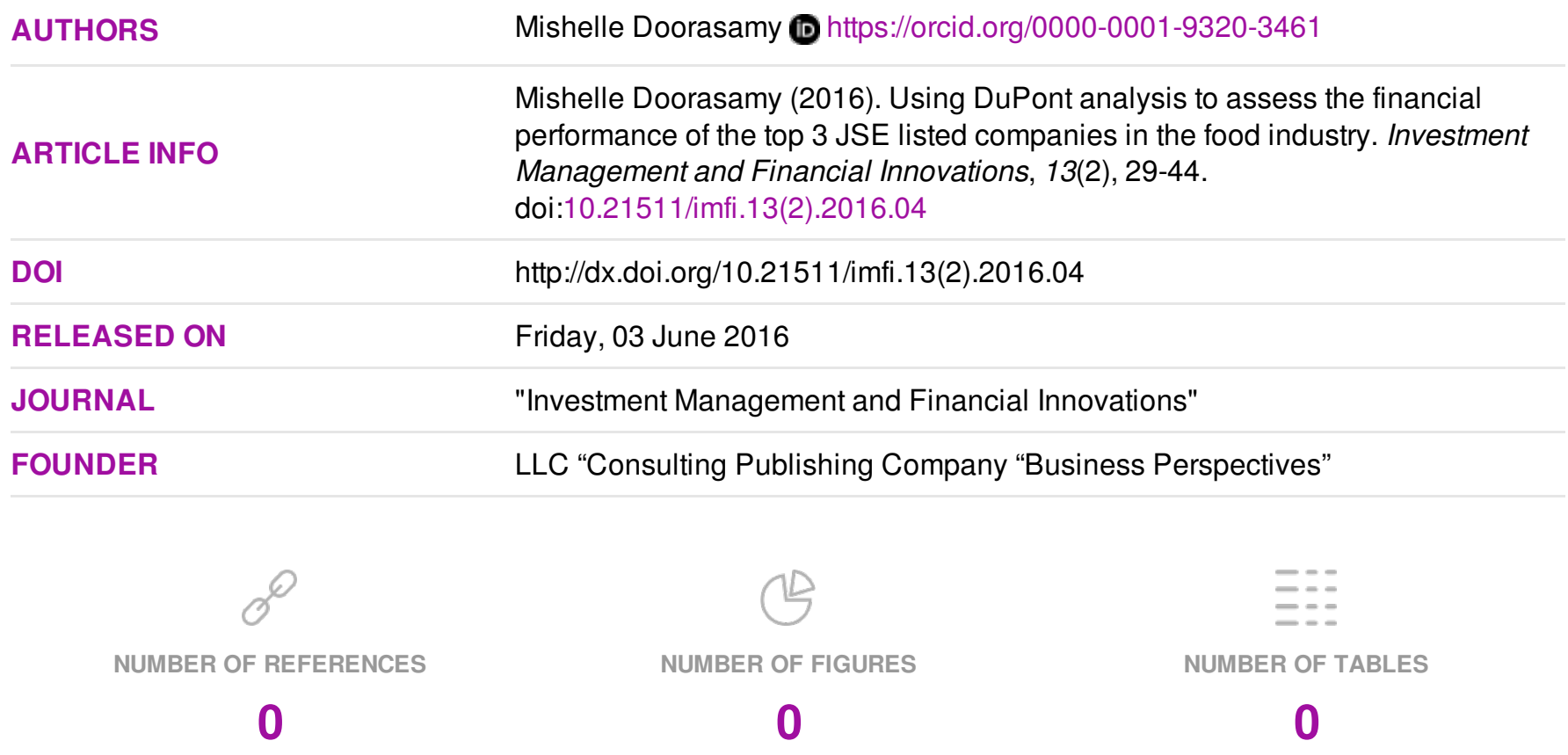

(C) The author(s) 2022. This publication is an open access article. 


\title{
Using DuPont analysis to assess the financial performance of the top 3 JSE listed companies in the food industry
}

\begin{abstract}
This study attempts to measure the financial performance of the food industry taking the top three JSE listed companies Pioneer Foods, Tiger Brands and RCI for the period of 2013-2014. In order to achieve the objectives of this research, ratios such as return on equity (ROE), return on assets (ROA) have been calculated by applying the DuPont analysis. The DuPont analysis is an important tool to measure the operating performance of a firm (Sheela and Karthikeyan, 2012). The volatility of the stock market makes investment decisions a controversial issue for most investors. Investments of huge amounts of money need proper analysis in order to make an informed decision. Financial statements are indicators of the profitability and financial sustainability of the business. Ratios are tools used to quantify the risk element before making any strategic decisions, more especially, investment decisions. It has been reported to be one of the most important financial ratios, because it provides investors with a more comprehensive measure of performance (Demmer, 2015). A detailed financial analysis of all three companies using the DuPont system shows that investing in Tiger Brands would generate a higher return to shareholders than Pioneer Foods or RCI.
\end{abstract}

Keywords: profitability, ratios, financial sustainability, financial analysis, investments, DuPont analysis, strategic decisions.

JEL Classification: C32, G10, G15.

\section{Introduction}

In publishing their financial statements, corporate organizations fully disclose matters concerning their operations to aid investors in making investment decisions (Blessing and Onoja, 2015). The goal of corporate managers is to maximize the value of the firm, which is determined by the investment and financing decisions made by the managers of the firm (McGowan and Stambaugh, 2012).

Ratios are used to establish the relationship between two variables and how they influence one another, and ratio analysis offers a means by which the financial and operational ills of a business enterprise can be effectively diagnosed (Agala, Jadhav and Borhade, 2014). Ratios also point out areas for further investigation. To guide decision making, managers analyze financial statements together with the ratios given. Analysis and interpretation of financial statements is an important tool in assessing the company's performance and gives investors an indication of the level of risk associated with that particular firm. For an investor, this is important and relevant information.

Different ratios are used to measure different aspects of the business in terms of performance, liquidity, riskiness and profitability. Of these possible indicators, literature indicates that the most important measure of profitability and performance is the one which is calculated using DuPont analysis. Demmer (2015) notes that changes in profit margin provide incremental information for

(C) Mishelle Doorasamy, 2016.

Mishelle Doorasamy, Lecturer, Department of Accounting, University of KwaZulu-Natal, Westville, Durban, South Africa. predicting changes in future return on assets, and Soliman (2008) cites DuPont components as yielding important information about the operating characteristics of a firm.

\section{Literature review}

1.1. Development of the DuPont model. The DuPont model was created in the early 1900s to assess the profitability of a business (Sheela and Karthikeyan, 2012). Modified twice after its initial conception, the original DuPont method of financial ratio analysis was developed in 1918 by F. Donaldson Brown, an engineer at DuPont in charge of understanding the finances of a company that DuPont was acquiring, who recognized a mathematical relationship between profitability and return on equity (ROE) that was determined by return on assets (ROA).

Since ROA impacts both profitability and efficiency, operating decisions of a firm in terms of planning and control will, thus, focus on increasing ROA, but the first modification of the DuPont model shifted the focus from ROA to ROE, incorporating debt or "leverage" as a third area of attention. This modification made the DuPont model a powerful tool for strategic decision making within an organization to increase ROE (Collier, McGowan and Muhammad, 2006).

The latest modification of the DuPont model incorporates a combination of five ratios to determine ROE. With the focus of annual statements from a managerial perspective being to assess a firm's financial performance, the significance of operating decisions (profitability and efficiency) and financing decisions (leverage) upon ROE continues to be important, and recent evidence has shown that 
this modified DuPont approach can be used to identify the causes of financial problems within manufacturing companies (Liesz and Maranville, 2008).

According to Rogova (2014), DuPont analysis effectively revealed factors of efficiency which had, in turn, impacted on the investment appeal of Russian oil-extracting companies. It was found that a strong advantage of ROE was the possibility of its disaggregation into different profitability ratios, with ROE indicating profitability and efficiency from the shareholders' point of view.

1.1.1. The DuPont analysis system. The DuPont system of financial analysis is based on return on equity, with the components of this ratio being the net profit margin, the total asset turnover and the equity multiplier (McGowan and Stambaugh, 2012). DuPont analysis is a preferred method to estimate the market value of a firm, indicating the leverage of a company to improve future profitability through more efficient utilization of its assets which will, in turn, improve the return to shareholders - higher leverage being preferable for potential investors. Demmer (2015) reports documentation in prior literature on the usefulness of DuPont disaggregation for predicting a firm's future profitability, operating income, and stock market returns and concludes that changes in profit margin provide important and relevant information on future return on assets. His findings also imply that DuPont components are partially influenced by the quality of the firms' expected earnings. He points to recent financial statement analysis (FSA) research which has shown the usefulness of change in profit margin for predicting year-ahead changes in RNOA (Demmer, 2015).

\subsubsection{Earnings quantity and the influence on} profitability forecasts. According to Dechow et al. (2010), the quality of earnings is recognized as higher when they provide more information about the features of a firm's financial performance for decision making, which, in turn, depends on the specific situation. It has also been stated in prior literature that the accounting system influences both future profitability and market reactions of a firm (Demmer, 2015).

Investment decisions affect the operating leverage of a firm, and financing decisions impact the degree of financial leverage of a firm. These, in turn, determine the future cash flows of the firm (Collier, McGowan and Muhammed, 2006). According to Soliman (2008), a change in asset turnover is positively related to future changes in earnings, and he goes on to discuss the extent to which competitive forces differently affect the profitability of a firm, noting that large profit margins draw new entrants into the market place or result in existing rivals imitating the new ideas. However, he found that competition may be less threatening to an efficient deployment of assets. If production processes are efficient, it makes it difficult to imitate another firms ideas due to the large cost factors involved. Soliman's findings contribute to literature on the sell-side analyst use of accounting information. He argues that if DuPont components map into equity value, analysts could use this information when creating forecasts and reviewing prior literature about the future profitability of the firm (Soliman, 2008).

Blessing and Onoja (2015) agree that profitability, assets, liabilities and equities are significant ways of evaluating performance reports of companies and for making investment decisions. They note a general belief that published financial statements have failed in their responsibility to provide credible information for investors and other users of financial statements.

1.2. Research objective. The main objective of this study is to ascertain the role of financial statements on investment decision making.

\section{Research methodology}

To test the research hypothesis, this study used secondary data from financial statements for 2013 and 2014 of the top three JSE listed food manufacturing companies, centred on Pioneer Foods, with its two main competitors, Tiger Brands and RCL Foods, used as comparatives. The model used for this research is good for investment decision making by potential investors and for policy-making purposes by banks and other corporate organizations.

\section{Financial analysis of the three companies}

3.1. Cash flow analysis. While the statement of profit or loss and other comprehensive income relays important information about the inflows and outflows of money in the business (using accrual accounting), the cash flow statement (using cash basis accounting) gives the true representation of the actual cash movement of the business for the financial year (McClure, 2015).

\subsection{Interpreting cash flow.}

Table 1. Operation cash flow/turnover

\begin{tabular}{|l|c|c|c|c|}
\hline \multicolumn{1}{|c|}{ Company } & Working & 2014 & Working & 2013 \\
\hline $\begin{array}{l}\text { Pioneer } \\
\text { Foods }\end{array}$ & $2154 / 17698.6$ & $12.17 \%$ & $1429 / 16240.9$ & $8.79 \%$ \\
\hline $\begin{array}{l}\text { Tiger Brands } \\
\text { competitor }\end{array}$ & $4193.2 / 30126.0$ & $13.92 \%$ & $3974.1 / 27064.7$ & $14.68 \%$ \\
\hline $\begin{array}{l}\text { RCL Foods } \\
\text { competitor }\end{array}$ & $1174 / 19719$ & $5.95 \%$ & $669 / 10108$ & $6.62 \%$ \\
\hline
\end{tabular}


The operating cash flow/turnover ratio shows how much cash is received per R1.00 of turnover (Alsemgeest, L., DuToit, E., Ngwenya, S. \& Thomas, K., 2014). Between 2013 and 2014 this ratio for Pioneer Foods rose from 8.79 percent (or $8.79 \mathrm{c}$ per R1.00 of turnover) to 12.17 percent, amounting to a 3.38 percent increase. This is beneficial for the company as more of its turnover is being converted to actual usable cash, and is also a good indicator for investors as it indicates a more liquid cash flow situation, with more money available to pay short-term debt.

Table 2. Free cash flow

\begin{tabular}{|l|c|c|c|c|}
\hline \multicolumn{1}{|c|}{ Company } & $\begin{array}{c}\text { Working } \\
\text { R mil }\end{array}$ & $\begin{array}{c}2014 \\
\text { R mil }\end{array}$ & $\begin{array}{c}\text { Working } \\
\text { R mil }\end{array}$ & $\begin{array}{c}2013 \\
\text { R mil }\end{array}$ \\
\hline Pioneer Foods & $1767.2-486$ & 1281.2 & $1196-828$ & 368 \\
\hline Tiger Brands competitor & $3106.9-983$ & 2123.9 & $2879.3-727.6$ & 2151.7 \\
\hline RCL Foods competitor & $638-653$ & $(15)$ & $610-476$ & 134 \\
\hline
\end{tabular}

Free cash flow is defined as net operating cash flow less capital expenditure (Accounting Coach, 2015). From 2013 to 2014, Pioneer Foods' free cash flow rose from R368 million to R1281.2 million, which is a 248 percent increase. In comparison, Tiger Brands 2014 free cash flow is R2123.9 million, a 1.29 percent decrease from 2013, and RCL Foods' 2014 free cash flow is negative at - R15 million. Free cash flow is an important indicator for investors; it shows that the company is in a strong position to avoid excessive borrowing and has the ability to expand its business and pay dividends (Loth, 2015). It is important that Pioneer Foods has a positive and growing free cash flow as it allows the company to follow opportunities that enhance shareholder wealth (McClure, 2015). Investors, would, thus see the increase in free cash flow of Pioneer Foods as an encouragingly positive indicator.

Table 3. Operating cash / total debt

\begin{tabular}{|l|c|c|c|c|}
\hline \multicolumn{1}{|c|}{ Company } & Working & 2014 & Working & 2013 \\
\hline $\begin{array}{l}\text { Pioneer } \\
\text { Foods }\end{array}$ & $1767.2 / 6229.3$ & $28.37 \%$ & $\mathbf{1 1 9 6 / 4 6 6 1 . 8}$ & $25.66 \%$ \\
\hline $\begin{array}{l}\text { Tiger Brands } \\
\text { competitor }\end{array}$ & $1639.7 / 10904.9$ & $15.04 \%$ & $1453.2 / 10726$ & $13.55 \%$ \\
\hline $\begin{array}{l}\text { RCL Foods } \\
\text { competitor }\end{array}$ & $666 / 10474$ & $6.36 \%$ & $\mathbf{6 1 0 / 1 0 3 4 7}$ & $5.86 \%$ \\
\hline
\end{tabular}

The ratio of cash generated from operating activities to total debts is 28.37 percent in 2014 and 25.66 percent in 2013 - an increase of 2.7 percent. This means that Pioneer Foods has generated sufficient cash to cover only 28.36 percent of its total debts. Although this ratio seems poor, in an industry-level comparison, it is 13.33 percent higher than its nearest competitor. Tiger Brands has a 15.04 percent ratio in 2014, 13.33 percent less than Pioneer Foods. RCL Foods has a 6.35 percent in 2014, 22.01 percent less than Pioneer Foods.
However, it is still in the company's best interest for Pioneer Foods to improve this ratio, as in the event of a market collapse it will not be able to meet its current liabilities, if it cannot convert its current assets into cash (McClure, 2015). This would compromize the liquidity of the company.

\section{DuPont ratio analysis}

In analyzing the performance of Pioneer Foods over the 2013-2014 time period, a suitable starting point would be a DuPont analysis (Correia et al., 2013) in which the following assumptions will apply (rand amounts shown in millions in each case):

- "Profit before tax" seen in the ratios is equal to the profits attributable to continuing operations.

- Average equity excludes non-controlling interests.

See Appendix A for the DuPont analysis ratios.

The 14.93 percent return on equity achieved by Pioneer Foods is highly satisfactory considered against the negative return on equity of -3.59 percent for RCL Foods. The poor performance by RCL Foods is chiefly attributable to strikes, coupled with a nationwide poultry industry crisis (News 24, 2014). Because Pioneer Foods has a diversified product range it was less affected by the poultry crisis. In addition, the company unbundled Quantum Foods, its poultryrelated division, and focused its resources on more profitable operations (Pioneer Foods, 2014). This strategy protected their returns in the face of a hostile market.

Tiger Brands achieved a return on equity of 15.33 percent, which is 0.4 percent higher than that of Pioneer Foods. Tiger Brands' performance can be attributed to its higher profit margin of 6.62 percent compared to a 5.35 percent profit margin for Pioneer Foods. Pioneer Foods is higher leveraged than Tiger Brands by only 0.01 times. The two companies thus, make similar use of leverage, yet Tiger Brands is more profitable.

The DuPont analysis shows that Tiger Brands would be more beneficial to invest in compared to either Pioneer or RCL Foods.

4.1. Liquidity. Liquidity refers to a company's ability to honour its short-term obligations (Correia et al., 2013). Adequate liquidity means that sufficient current assets are available to cover the current liabilities (Correia et al., 2013).

Table 4. Current ratio

\begin{tabular}{|c|c|c|c|c|}
\hline \multicolumn{5}{|c|}{ 1. Current ratio $=$ current assets: current liabilities } \\
\hline \multicolumn{3}{|c|}{ Pioneer Foods } & Tiger Brands & $\mathrm{RCL}$ \\
\hline 2014 & 2013 & 2012 & 2014 & 2014 \\
\hline $\begin{array}{c}5420.9 / \\
3920.7= \\
1.38: 1\end{array}$ & $\begin{array}{c}4416.1 / \\
2357.2= \\
1.87: 1\end{array}$ & $\begin{array}{c}5079.6 / \\
3035.5= \\
1.67: 1\end{array}$ & $\begin{array}{c}10728.3 / \\
9371.9= \\
1.14: 1\end{array}$ & $\begin{array}{c}7789 / \\
8478.1= \\
0.91: 1\end{array}$ \\
\hline
\end{tabular}


Table 4 (cont.). Current ratio

\begin{tabular}{|c|c|c|c|c|}
\hline \multicolumn{5}{|c|}{ 2. Quick ratio = current assetsinventory: current liabilities } \\
\hline \multicolumn{3}{|c|}{ Pioneer foods } & Tiger brands & $\mathrm{RCL}$ \\
\hline 2014 & 2013 & 2012 & 2014 & 2014 \\
\hline $\begin{array}{c}2997.6 / \\
3920.7= \\
0.76: 1\end{array}$ & $\begin{array}{c}2014.9 / \\
2357.2= \\
0.85: 1\end{array}$ & $\begin{array}{c}2629.7 / \\
3035.5= \\
0.87: 1\end{array}$ & $\begin{array}{c}6027.7 / \\
9371.9= \\
0.64: 1\end{array}$ & $\begin{array}{c}5631.7 / \\
8478.1= \\
0.12: 1\end{array}$ \\
\hline \multicolumn{5}{|c|}{ 3. Cash ratio = cash: current liabilities } \\
\hline $\begin{array}{c}1107.6 / \\
3920.7= \\
0.28: 1\end{array}$ & $\begin{array}{c}379 / \\
2357.2= \\
0.16: 1\end{array}$ & $\begin{array}{c}375.6 / \\
3035.5= \\
0.12: 1\end{array}$ & $\begin{array}{c}1160.3 / \\
9371.9= \\
0.12: 1\end{array}$ & $\begin{array}{c}1047.7 / \\
8478.1= \\
0.12: 1\end{array}$ \\
\hline
\end{tabular}

Pioneer Foods' current ratio for year 2014 is 1.38:1, which is a 26.2 percent decrease from 2013 (1.87:1). This still indicates a liquid situation for Pioneer Foods, however, as the company can pay off short-term debts with their current assets. Its current ratio for 2014 is $1.38: 1$, which is $0.24: 1$ greater than Tiger Brands (1.14:1) and 0.47:1 greater than RCL Foods (0.91:1). This indicates that Pioneer Foods is more liquid than the industry in relation to current ratio.

Although the quick ratio for Pioneer Foods has decreased from 0.85:1 (2013) to 0.76:1 (2014), the 2014 quick ratios for Tiger Brands and RCL Foods are $0.64: 1$ and $0.66: 1$, respectively, indicating that Pioneer Foods is above the industry norm, and, thus, more liquid in terms of the quick ratio. However, the decrease in the quick ratio is still disadvantageous to Pioneer Foods, firstly, because it shows a declining liquidity position, and, secondly, because it may indicate that the company is holding too much inventory, since the decrease between current ratio and quick ratio is the greatest for Pioneer Foods (44.92 percent). Holding too much inventory implies that Pioneer Foods may be tying up too much money in inventory that it could, instead, be investing to receiving an investment return. Holding too much stock could also mean higher risk of obsolete stock (Correia et al., 2013).

The cash ratio shows how much cash the company has available to cover its current liabilities (Correia et al., 2013). Pioneer Foods' cash ratio has risen from $0.16: 1$ (2013) to $0.28: 1$ (2014). This is positive as it means money is available to pay off short-term debts. In comparison with industry competitors, Pioneer Foods has a much higher cash ratio than both Tiger Brands $(0.12: 1)$ and $\mathrm{RCL}$ Foods (0.12:1).

Pioneer Foods has shown to be slightly less liquid than in prior years, but still more liquid than Tiger Brands and RCL Foods.

4.2. Solvency and financial leverage. Solvency measures the ability of the company to pay its longterm obligations using the total assets of the company (Correia et al., 2013).
Table 5. Debt - asset ratio

\begin{tabular}{|c|c|c|c|c|}
\hline \multicolumn{5}{|c|}{ Debt - asset $=$ total debt: total assets } \\
\hline \multicolumn{3}{|c|}{ Pioneer Foods } & $\begin{array}{c}\text { Tiger } \\
\text { Brands }\end{array}$ & RCL \\
\hline 2014 & 2013 & 2012 & 2014 & 2014 \\
\hline $6229.3 /$ & $4661.8 /$ & $4413.1 /$ & $10904.8 /$ & $10474.5 /$ \\
$12910.2=$ & $11734.4=$ & $10606.2=$ & $24852=$ & $19910.8=$ \\
0.48 & 0.40 & 0.42 & 0.44 & 0.53 \\
\hline
\end{tabular}

The debt asset ratio shows the relationship between debt and total assets, which provides an indication of the portion of the total capital that is financed by means of debt capital (Correia et al., 2013). The higher the value of this ratio, the weaker the solvency of the business (Alsemgeest et al., 2014)

In 2014, 48 percent of the company's assets were financed by debt; a deterioration from prior yearly figures of 40 percent (2013) and 42 percent (2012). However, the increase in risk which accompanies the use of more debt capital has led to an improvement in profitability ratios (discussed below), which is the ultimate goal in utilizing more debt. Pioneer Foods also has a slightly worse solvency position than Tiger Brands, with only 44 percent of Tiger Brands assets having been financed by debt. Pioneer Foods' solvency position is more favorable than RCL Foods, which has 53 percent of its assets financed by debt.

Table 6. Debt - equity ratio

\begin{tabular}{|c|c|c|c|c|}
\hline \multicolumn{5}{|c|}{ Debt - equity = total debt: total equity } \\
\hline \multicolumn{3}{|c|}{ Pioneer Foods } & Tiger Brands & $\mathrm{RCL}$ \\
\hline 2014 & 2013 & 2012 & 2014 & 2014 \\
\hline $\begin{array}{c}6229.3 / \\
6112.8= \\
1.02\end{array}$ & $\begin{array}{c}4661.8 / \\
6590.6= \\
0.71\end{array}$ & $\begin{array}{c}4413.1 / \\
6193.1= \\
0.71\end{array}$ & $\begin{array}{c}10904.8 / \\
13947.2= \\
0.78\end{array}$ & $\begin{array}{c}10474.5 / \\
9436.3= \\
1.11\end{array}$ \\
\hline
\end{tabular}

The debt - equity ratio compares the amount of debt capital with equity capital (Correia et al., 2013). In 2014, debt capital exceeded equity capital by 0.02 percent. This is a decline in Pioneer Foods' solvency, with an increase in debt - equity ratio from 0.71 in the prior years to 1.02 in the current year. Thus, in 20146 Pioneer Foods (at 102 percent) had a weaker solvency position compared to Tiger Brands, which had 78 percent of debt capital, and a better solvency position than RCL, which had 111 percent of debt capital. An increase in the use of debt is a concern as it increases the financial risk that a company faces, as well as the finance charges, with adverse effect on profit (Alsemgeest et al., 2014).

Table 7. Finance cost coverage ratio

\begin{tabular}{|c|c|c|c|c|}
\hline \multicolumn{4}{|c|}{ Finance cost coverage = earnings before interest and tax / finance cost } \\
\hline \multicolumn{3}{|c|}{ Pioneer Foods } & $\begin{array}{c}\text { Tiger } \\
\text { Brands }\end{array}$ & $\mathrm{RCL}$ \\
\hline 2014 & 2013 & 2012 & 2014 & 2014 \\
\hline $1537.9 /$ & $1064.7 /$ & $1066.1 /$ & $3125.2 /$ & $692.7 /$ \\
138 & 125.5 & 136.1 & 429 & $=7.28$ \\
$=11.14$ & $=8.48$ times & $=7.83$ times & $\begin{array}{c}1043.5 \\
\text { times }\end{array}$ & 0.66 times \\
times & & & & \\
\hline
\end{tabular}


The finance cost coverage ratio indicates whether there are sufficient profits available to pay the finance cost charge (Correia et al., 2013). In 2014, the finance cost coverage ratio is sufficient, as an amount of R11.14 is available to cover each R1.00 of finance cost that needs to be paid. This is an improvement from 2013 (where the corresponding cost coverage ratio was 8.48 times) and 2012 (where it was 7.83 times). This ratio suggests that Pioneer Foods has a better solvency position than Tiger Brands and RCL, for which cost coverage availability was only 7.28 times and 0.66 , respectively.

Table 8. Financial leverage ratio

\begin{tabular}{|c|c|c|c|c|}
\hline \multicolumn{5}{|c|}{ Finance leverage $=$ average total assets $/$ average total equity } \\
\hline \multicolumn{3}{|c|}{ Pioneer Foods } & Tiger Brands & $\mathrm{RCL}$ \\
\hline 2014 & 2013 & 2012 & 2014 & 2014 \\
\hline $12322.3 /$ & $11238.5 /$ & $10234.6 /$ & $25046.5 /$ & $18651.4 /$ \\
\hline $\begin{array}{c}6341.85= \\
1.94\end{array}$ & $\begin{array}{c}6389.8= \\
1.76\end{array}$ & $\begin{array}{c}5844.4= \\
1.75\end{array}$ & $\begin{array}{c}12982.25= \\
1.93\end{array}$ & $\begin{array}{c}8240.9= \\
2.32\end{array}$ \\
\hline
\end{tabular}

As discussed in the DuPont analysis (Appendix 1), the financial leverage ratio compares the average amount of total assets with the average amount of equity capital included in the company's capital structure (Alsemgeest et al., 2014). Pioneer Foods' financial leverage in 2014 was 1.94, an increase from 1.76 in 2013, which indicates an increase in portion of debt capital utilized by the company. Pioneer Foods has a slightly worse leveraged position than Tiger Brands (1.93) but a better solvency position than RCL (2.32) profitability.

Profitability refers to the efficiency with which a company utilizes its capital to generate turnover (Alsemgeest et al., 2014).

Table 9. Gross profit margin

\begin{tabular}{|c|c|c|c|c|}
\hline \multicolumn{5}{|c|}{ Gross profit margin on sales = gross profit $/$ sales } \\
\hline \multicolumn{3}{|c|}{ Pioneer Foods } & Tiger Brands & $\mathrm{RCL}$ \\
\hline 2014 & 2013 & 2012 & 2014 & 2014 \\
\hline $\begin{array}{c}5377.4 / \\
17698.6= \\
30.38 \%\end{array}$ & $\begin{array}{c}4713.4 / \\
16240.9= \\
29.02 \%\end{array}$ & $\begin{array}{l}4677.0 / \\
15534.5 \\
=30.11\end{array}$ & $\begin{array}{l}9531.8 / \\
30072= \\
31.70 \%\end{array}$ & $\begin{array}{l}4811.3 / \\
19720= \\
24.40 \%\end{array}$ \\
\hline
\end{tabular}

The gross profit margin is an indication of the portion of the company's turnover that is realized as gross profit after the cost of sales has been subtracted (Correia et al., 2013). This ratio decreased from 2012 (30.11 percent) to 2013 (29.02 percent) and increased from 2013 to 2014 (30.38 percent). This fluctuation is attributable to change in revenue growth, above the rate of inflation. In 2014, revenue from continuing operations increased by 9 percent to R17.7 billion, mainly due to increase in the mix of selling prices, exports and sales (Pioneer Foods, 2014). Notably, this favorable increase occurred despite the discontinuation of Quantum Foods which took place subsequent to the 2014 year end. Pioneer Foods has a higher gross profit margin than RCL Foods ( 24.40 percent) which suggests that it is more profitable, and, perhaps, has more buying power that allows it to request cheaper materials from suppliers.

However, Tiger Brands is slightly more profitable than Pioneer Foods as it makes a gross profit of R31.70 for every R100 worth of sales. Tiger Brands' performance is expected as it has the highest revenue, while still apparently able to control its cost of sales efficiently and consistently.

Table 10. Net profit margin

\begin{tabular}{|c|c|c|c|c|}
\hline \multicolumn{5}{|c|}{ Net profit margin on sales $=$ net profit $/$ sales } \\
\hline \multicolumn{3}{|c|}{ Pioneer Foods } & Tiger Brands & RCL \\
\hline 2014 & 2013 & 2012 & 2014 & 2014 \\
\hline $\begin{array}{c}947 / \\
17698.6= \\
5.35 \%\end{array}$ & $\begin{array}{c}699 / \\
16240.9= \\
4.30 \%\end{array}$ & $\begin{array}{c}610.6 / \\
15534.5= \\
3.93 \%\end{array}$ & $\begin{array}{c}1990.3 / \\
30072= \\
6.62 \%\end{array}$ & $\begin{array}{c}-289 / \\
19720=- \\
1.47 \%\end{array}$ \\
\hline
\end{tabular}

The net profit margin indicates how much revenue is available after tax is paid (Alsemgeest et al., 2014). Pioneer Foods' net profit margin is 5.35 percent in 2014, a 1.05 percent increase from 2013. This suggests, at a surface level, that management has proportionately decreased expenses relative to the increase in net profit, indicating reduced inefficiencies. This improvement is also attributable to the increase in net profit that the company has been experiencing from the year 2012 to the current year. The improvement in the net profits of the company in 2014 may be attributable to profit made from the discontinued operation (Quantum Foods) of R18.2 million, compared to the loss of R200.4 million made in 2013 financial year. Notably, profitability was reduced because of a R36.3 increase from 2013 in the impairment of the company's investment in the Pepsi business.

Pioneer Foods has a lower net profit margin than Tiger Brands (6.62 percent), but a higher net profit margin than RCL Foods (-1.47 percent). This is expected, as Tiger Brands has been generating higher revenues in the current year. Compared to Pioneer Foods, RCL Foods has been experiencing losses. The loss suffered by RCL Foods in 2014 is mainly caused by a R889 783 increase in finance costs from 2013 (the company has compulsory redeemable preference shares which means they recognize dividends as a finance cost).

Table 11. Return on ordinary shareholders' equity

\begin{tabular}{|c|c|c|c|c|}
\hline \multicolumn{5}{|c|}{$\begin{array}{l}\text { Return on ordinary shareholder's equity = profit after tax- non-controlling } \\
\text { interest-preference dividends / average ordinary shareholders equity }\end{array}$} \\
\hline \multicolumn{3}{|c|}{ Pioneer Foods } & Tiger Brands & $\mathrm{RCL}$ \\
\hline 2014 & 2013 & 2012 & 2014 & 2014 \\
\hline $\begin{array}{c}947 / 1 \\
6341.9= \\
14.93 \%\end{array}$ & $\begin{array}{c}699 / \\
6383.1= \\
10.95 \%\end{array}$ & $\begin{array}{c}610.6 / \\
5836.6= \\
10.46 \%\end{array}$ & $\begin{array}{c}1990.3 / \\
12982.3= \\
15.33 \%\end{array}$ & $\begin{array}{c}-289.0 / \\
8054.4= \\
-3.59\end{array}$ \\
\hline
\end{tabular}


The return on ordinary shareholders equity measures how much the ordinary shareholders earned for their investment in the company (Alsemgeest et al., 2014). Pioneer Foods' return on ordinary shareholders equity for 2014 is 14.93 percent, which is 3.98 percent more than 2013 (10.95 percent). This improvement was mainly caused by a substantial increase in profits, further assisted by a decrease in equity. This higher ratio indicates that management is more efficient in utilizing its equity base, ultimately leading to better return for investors.

Tiger Brands has a higher return on shareholders' equity than Pioneer Foods, as for every R100 investment in Tiger Brands, ordinary shareholders receive a return of $\mathrm{R} 15.33$ as compared to a return of R14.93 from Pioneer Foods. However, the Pioneer Foods' return is greater than the RCL Foods' negative return of -3.59 percent.

4.3. Asset management. Asset management ratios are designed to determine how effectively the assets of the company are being utilized (Correia et al., 2013).

Inventory turnover days.

Inventory turnover days are calculated according to the formula:

Inventory turnover days $=$ average inventory $/$ cost of sales $\times 365$.

Indicate that the average number of days that inventory is on hand before being sold (Alsemgeest et al., 2014). There has been a favourable 5.34 day decrease in the Pioneer Foods inventory turnover days, from 76.8 days in 2013 to 71.46 days in 2014 . This is due to the consumption of their goods increasing over the year, evidenced in their increased market share in core categories (Pioneer Foods, 2014). Additionally, the ratio is 11.65 days lower than that of Tiger Brands (83.11 days), which is a positive indication that Pioneer Foods is running through its stock at a faster rate than its main competitor. The company, is thus, at decreased risk of product spoilage in relation both to prior years and to Tiger Brands. RCL Foods (at 40.88 days), on the other hand, has an inventory turnover ratio that is 30.58 days lower than that of Pioneer Foods, but not too much should be read into this comparison as RCL Foods mainly deals in poultry which has a shorter shelf life and, thus, quicke rinventory turnover than the bulk of Pioneer Foods products such as cereals. The figure do, nonetheless, suggest that Pioneer Foods may have to take further initiatives to continue improving the ratio.

4.4. Average collection period. The average collection period ratio is calculated according to the formula:
Average collection period $=$ average trade receivables* / sales $\times 365$,

where $*$ is calculated using net trade receivables (being trade receivables less impairment provision), as stated in the Trade and other receivables Note.

Indicate the average number of days, it takes debtors to pay the company (Alsemgeest et al., 2014). Pioneer Foods' average collection period has decreased by 5.21 days from 37.57 days (2013) to 32.36 days (2014). Thus, debtors are paying Pioneer Foods more quickly than in the previous year, placing the company at decreased risk of bad debts and poor cash flow. Additionally, Pioneer Foods has indicated that the credit quality of its customer base is considered to be good based on historical default rates (Pioneer Foods, 2014).

In relation to their competitors, Pioneer Foods has a much lower risk of bad debts, as Tiger Brands (42.17 days) and RCL Foods (40.79 days) debtors, respectively, take 9.81 and 8.43 days longer to pay. Further discussion on the implications of this ratio is continued below in relation to the working capital ratio.

Table 12. Fixed asset turnover ratio

\begin{tabular}{|c|c|c|c|c|}
\hline \multicolumn{5}{|c|}{ Fixed asset turnover ratio = sales / average non-current assets } \\
\hline \multicolumn{3}{|c|}{ Pioneer Foods } & Tiger Brands & $\mathrm{RCL}$ \\
\hline 2014 & 2013 & 2012 & 2014 & 2014 \\
\hline $\begin{array}{c}17698.6 / \\
5393.7= \\
3.28 \text { times }\end{array}$ & $\begin{array}{c}16240.9 / \\
5445.8= \\
2.98 \text { times }\end{array}$ & $\begin{array}{l}15534.5 \text { I } \\
5282.2= \\
2.94 \text { times }\end{array}$ & $\begin{array}{c}30126 / \\
14939.6= \\
2.02 \text { times }\end{array}$ & $\begin{array}{c}19720 / \\
10859.5= \\
1.82 \text { times }\end{array}$ \\
\hline
\end{tabular}

The fixed asset turnover ratio measures the utilization of all the company's operating assets in relation to sales revenue (Correia et al., 2013). This ratio is of particular interest as Pioneer Foods falls within the manufacturing industry. The ratio has shown a favorable increase from 2013 (2.98 times) to 2014 (3.28 times). This means that the company has over the years used its assets to generate higher returns. This ratio is 1.26 times and 1.46 times higher, respectively, than those of Tiger Brands (2.02 times) and RCL Foods (1.82 times). This means that Pioneer Foods utilizes its fixed assets more efficiently than its competitors.

4.5. Trade payable days. Trade payable days are calculated according to the formula:

Trade payable days $=$ average trade payable* $/$ cost of sales $\times 365$,

where $*$ is calculated using trade payable as found in the Notes to the Financial Statements.

Measure the number of days on average, it takes a company to pay its creditors (Correia et al., 2013). Pioneer Foods has taken, on average, 1.15 days longer to pay their trade creditors in 2014 (49.76 
days) than in 2013 (48.61 days). The increase in trade payable days indicates that the company is taking advantage of the credit that is available to them, allowing themselves a longer time to recover the funds to pay creditors (Correia et al., 2013). This ratio is certainly favorable as it is higher than the average collection period of debtors calculated above to be 32.36 days in 2014. This means that Pioneer Foods is receiving money owed to it before having to pay their creditors - a favorable cash flow position.

This has not put the company at an increased risk of incurring interest on overdue accounts, since perusal of its financial statements reveals that it has not incurred any interest on trade payables (Pioneer Foods, 2014). The Pioneer Foods ratio is 19.66 days longer than that of Tiger Brands (30.10 days) and 1.84 days longer than that of RCL Foods, thus giving Pioneer Foods a better cash flow position than the industry at large, which is a positive indicator for investors (Correia et al., 2013).

Table 13. Working capital cycle

\begin{tabular}{|c|c|c|}
\hline \multicolumn{3}{|l|}{$\begin{array}{l}\text { Working capital cycle }=\text { inventory turnover days }+ \text { average collection } \\
\text { period }- \text { Trade payables days }\end{array}$} \\
\hline Pioneer Foods & Tiger Brands & RCL \\
\hline $\begin{array}{c}71.46+32.36-49.76 \\
=54.06 \text { days }\end{array}$ & $\begin{array}{c}83.11+42.17-30.10 \\
=95.18 \text { days }\end{array}$ & $\begin{array}{c}40.88+40.79-47.92 \\
=33.75 \text { days }\end{array}$ \\
\hline
\end{tabular}

The longer the working capital cycle of an entity, the longer the working capital of the business is tied up in the cycle without earning a return on it (Correia et al., 2013). For the year 2014, Pioneer Foods (54.06 days) has a working capital cycle that is 41.12 days shorter than that of Tiger Brands (95.18 days), but 20.31 days longer than that of RCL (33.75 days).

In this respect, Pioneer is earning returns on its working capital at a much faster rate than Tiger Brands, but at a slighter slower rate than RCL Foods. The company may improve its cycle by encouraging debtors to pay it sooner or by researching alternate ways in which it may improve inventory turnover. However, as discussed above, the comparison between Tiger Brands and Pioneer Foods has greater significance as these two companies produce similar goods, whereas the major focus of RCL Foods is on poultry. Analysis of the asset management ratios indicates a favorable trend in the efficiency of asset utilization by Pioneer Foods. This is a positive indicator for both existing and prospective investors, particularly, if the trend continues.

4.6. Market value. Market value ratios provide an indication of the market perception of the company's past performance and future prospects (Correia et al., 2013).
Table 14. Dividend yield ratio

\begin{tabular}{|c|c|c|c|c|}
\hline \multicolumn{5}{|c|}{ Dividend yield ratio $=$ dividend per share ${ }^{*} /$ price per share ${ }^{\#}$} \\
\hline \multicolumn{3}{|c|}{ Pioneer Foods } & Tiger Brands & $\mathrm{RCL}$ \\
\hline 2014 & 2013 & 2012 & 2014 & 2014 \\
\hline $\begin{array}{c}221 c / \\
11800 c= \\
1.87 \%\end{array}$ & $\begin{array}{c}132 \mathrm{c} / \\
8750 \mathrm{c}= \\
1.51 \%\end{array}$ & $\begin{array}{c}114 c / \\
5300 c= \\
2.15 \%\end{array}$ & $\begin{array}{c}940 c / \\
31543 c= \\
2.98 \%\end{array}$ & $\begin{array}{c}20 c / \\
1580 c= \\
1.27 \%\end{array}$ \\
\hline
\end{tabular}

Notes: * The Pioneer Foods dividend per share for 2014 excludes the dividend in specie declared with the unbundling of Quantum Foods. ${ }^{\#}$ The share price utilized in all market ratio calculations is the price at year end for all the companies. Year ends as follows: Pioneer Foods and Tiger Brands year end: 30 September; RCL Foods: 30 June. This affects analysis as market forces and conditions prevailing on 30 June 2014 differ from market conditions on 30 September 2014.

Dividend yield shows how much a company pays out in dividends each year relative to its share price (Investopedia, 2015a). The dividend yield for Pioneer Foods decreased by 0.64 percent in 2013 (1.51 percent) from 2012 (2.15 percent), but shows a favorable increase of 0.36 percent in 2014 (1.87 percent). This means that shareholders received a higher return on their investment in the form of dividends in 2014 compared to 2013.

The return received by Pioneer Foods shareholders is 0.6 percent higher than the return for RCL Foods (1.27 percent), but is 1.11 percent lower than the return for Tiger Brands (2.98 percent). This indicates that Tiger Brands is likely to be the most favorably viewed of the three companies by investors as its shareholders receive the highest return on their investment.

Table 15. Earnings yield

\begin{tabular}{|c|c|c|c|c|}
\hline \multicolumn{5}{|c|}{ Earnings yield = headline earnings per share / price per share } \\
\hline \multicolumn{3}{|c|}{ Pioneer Foods } & Tiger Brands & $\mathrm{RCL}$ \\
\hline 2014 & 2013 & 2012 & 2014 & 2014 \\
\hline $\begin{array}{c}575.6 c / \\
11800 c= \\
4.88 \%\end{array}$ & $\begin{array}{c}389.8 \mathrm{c} / \\
8750 \mathrm{c}= \\
4.45 \%\end{array}$ & $\begin{array}{c}337.1 \mathrm{c} / \\
5300 \mathrm{c}= \\
6.36 \%\end{array}$ & $\begin{array}{c}1816 c / \\
31543 c= \\
5.76 \%\end{array}$ & $\begin{array}{c}-47.7 c / \\
1580 c=- \\
3.02 \%\end{array}$ \\
\hline
\end{tabular}

Earnings yield indicates the yield investors are demanding (Correia et al., 2013). Earnings yield declined by 1.91 percent in 2013 (4.45 percent), from 6.36 percent in 2012. It has favorably increased by 0.43 percent in 2014 (4.88 percent).

The earnings yield achieved by Pioneer Foods for 2014 is 0.88 percent lower than that achieved by Tiger Brands (5.76 percent). In relation to RCL Foods, Pioneer Foods has an earnings yield that is 7.9 percent more favorable.

Table 16. Dividend cover ratio

\begin{tabular}{|c|c|c|c|c|}
\hline \multicolumn{5}{|c|}{ Dividend cover ratio $=$ headline earnings per share $/$ dividend per share } \\
\hline \multicolumn{3}{|c|}{ Pioneer Foods } & \multirow{2}{*}{$\begin{array}{c}\begin{array}{c}\text { Tiger } \\
\text { Brands }\end{array} \\
2014\end{array}$} & \multirow{2}{*}{$\begin{array}{c}\mathrm{RCL} \\
2014\end{array}$} \\
\hline 2014 & 2013 & 2012 & & \\
\hline $\begin{array}{c}575.6 \mathrm{c} / \\
221 \mathrm{c}= \\
2.60 \text { times }\end{array}$ & $\begin{array}{c}389.8 \mathrm{c} / \\
132 \mathrm{c}= \\
2.95 \text { times }\end{array}$ & $\begin{array}{c}337.1 \mathrm{c} / \\
114 \mathrm{c}= \\
2.95 \text { times }\end{array}$ & $\begin{array}{c}1816 c / \\
940 c= \\
1.93 \text { times }\end{array}$ & $\begin{array}{c}-47.7 c / 20 c= \\
-2.39 \text { times }\end{array}$ \\
\hline
\end{tabular}


The dividend cover ratio measures the earnings that are being paid out in the form of dividends (Correia et al., 2013). In 2012 and 2013, the dividend cover ratio remained constant for Pioneer Foods at a factor of 2.95 , and, then, declined by 0.35 in 2014 to 2.60 . A larger percentage of earnings is, thus, being retained by Pioneer Foods for future reinvestments, which may not discourage investors as their longterm wealth is being taken into account.

Pioneer Foods also retains more of its earnings, in comparison with its competitors. Tiger Brands (1.93) and RCL Foods (-2.39) have ratios that, respectively, are 0.67 times and 4.99 times lower than that of Pioneer Foods. This is indicative of the competitors adopting different strategic approaches to that of Pioneer.

Table 17. Price: earnings ratio

\begin{tabular}{|c|c|c|c|c|}
\hline \multicolumn{5}{|c|}{ Price-earnings ratio $=$ price per share $/$ headline earnings per share } \\
\hline \multicolumn{3}{|c|}{ Pioneer Foods } & Tiger Brands & $\mathrm{RCL}$ \\
\hline 2014 & 2013 & 2012 & 2014 & 2014 \\
\hline $\begin{array}{c}11800 \mathrm{c} / \\
575.6= \\
20.51 \text { times }\end{array}$ & $\begin{array}{c}8750 \mathrm{c} / \\
389.8 \mathrm{c}= \\
22.45 \text { times }\end{array}$ & $\begin{array}{c}5300 \mathrm{c} / \\
337.1 \mathrm{c}= \\
15.72 \text { times }\end{array}$ & $\begin{array}{c}31543 \mathrm{c} / \\
1816 \mathrm{c}= \\
17.37 \text { times }\end{array}$ & $\begin{array}{c}1580 \mathrm{c} /- \\
47.7 \mathrm{c}=- \\
33.1 \text { times }\end{array}$ \\
\hline
\end{tabular}

The price-earnings ratio is the inverse of the earnings yield ratio. It is ratio of a company's current share price compared to its per-share earnings (Investopedia, 2014). Pioneer Foods' ratio has shown a positive increase by a factor of 6.73 in 2013 (22.45 times) from 2012 (15.72 times). The price-earnings ratio ( $\mathrm{P} / \mathrm{E}$ ratio) declined by a factor of 1.94 in 2014 (20.51 times).

Despite the decrease in the $\mathrm{P} / \mathrm{E}$ ratio, investors are still willing to pay more per rand of reported profits for Pioneer Foods than for its competitors. Tiger Brands has a ratio (17.37 times) that is lower than that of Pioneer Foods by a factor of 3.14, while the ratio for RCL Foods (-33.1 times) is lower than that of Pioneer Foods by a factor of 53.61. This shows that Pioneer Foods is perceived as having high growth prospects in the future (Investopedia, 2014).

Using the $\mathrm{P} / \mathrm{E}$ ratio, it should, thus, be noted that investors would pay more money to receive R1.00 of Pioneer Foods earnings than for earnings from either Tiger Brands or RCL Foods.

Table 18. Market to book value ratio

\begin{tabular}{|c|c|c|c|c|}
\hline \multicolumn{5}{|c|}{ Market to book value ratio = price per share / net asset value per share } \\
\hline \multicolumn{3}{|c|}{ Pioneer Foods } & Tiger Brands & $\mathrm{RCL}$ \\
\hline 2014 & 2013 & 2012 & 2014 & 2014 \\
\hline $\begin{array}{c}11800 \mathrm{c} / \\
575.6= \\
20.51 \text { times }\end{array}$ & $\begin{array}{c}8750 \mathrm{c} / \\
389.8 \mathrm{c}= \\
22.45 \text { times }\end{array}$ & $\begin{array}{c}5300 \mathrm{c} / \\
337.1 \mathrm{c}= \\
15.72 \\
\text { times }\end{array}$ & $\begin{array}{c}31543 \mathrm{c} / \\
1816 \mathrm{c}= \\
17.37 \text { times }\end{array}$ & $\begin{array}{c}1580 \mathrm{c} / \\
-47.7 \mathrm{c}= \\
-33.1 \\
\text { times }\end{array}$ \\
\hline
\end{tabular}

Market to book value ratio compares the market value of the firm's investment to its costs (Firer, Ross, Westerfield and Jordan, 2004). The ratio for
Pioneer Foods increased year on year by 0.88 times in 2013 (2.43 times) and by 1.13 times in 2014 (3.56 times). This indicates that Pioneer Foods has been increasingly able to create value for its shareholders (Firer et al., 2004).

Pioneer Foods' ratio is 2012 times higher than that of RCL (1.44 times) which indicates that Pioneer Foods has been more successful in the creation of shareholder wealth. Tiger Brands, however, has a ratio 0.28 times higher than that of Pioneer Foods. This is indicative of shareholder being willing to pay more for a share in Tiger Brands than for Pioneer Foods.

\subsection{Earnings per share.}

Table 19. Earnings per share (in cents)

\begin{tabular}{|l|c|c|c|c|c|c|}
\hline & \multicolumn{2}{|c|}{ Pioneer Foods* $^{*}$} & \multicolumn{2}{c|}{ Tiger Brands } & \multicolumn{2}{c|}{ RCL Foods } \\
\cline { 2 - 8 } & 2014 & 2013 & 2014 & 2013 & 2014 & 2013 \\
\hline Basic EPS & 516.6 & 385.5 & 1245.9 & 1574.9 & $(45.7)$ & 4.5 \\
\hline Diluted basic EPS & 492.9 & 376.3 & 1212.5 & 1535.8 & $(45.7)$ & $(4.4)$ \\
\hline Headline EPS & 637.4 & 466.5 & 1804.4 & 1574.3 & $(47.7)$ & 4.8 \\
\hline Diluted headline EPS & 608.2 & 455.2 & 1760.2 & 1535.2 & $(47.7)$ & $(4.8)$ \\
\hline
\end{tabular}

Notes: * Pioneer Foods' headline earnings adjusted for the impact of the share-based payment charge on the B-BBEE Phase 1 transaction due to volatility and non-repetitive nature of the Quantum Foods effect on profits (non-recurring item).

Table 20. EPS trends 2013-2014

\begin{tabular}{|l|c|c|c|}
\hline \multicolumn{1}{|c|}{$2013-2014$ trends } & Pioneer Foods & Tiger Brands & RCL Foods \\
\hline Basic EPS & $+34.01 \%$ & $-21.08 \%$ & $-1115.56 \%$ \\
\hline Diluted EPS & $+30.99 \%$ & $-21.05 \%$ & $-938.64 \%$ \\
\hline Headline EPS & $+36.63 \%$ & $+14.62 \%$ & $-1093.75 \%$ \\
\hline Diluted headline EPS & $+33.61 \%$ & $+11.14 \%$ & $-1093.75 \%$ \\
\hline
\end{tabular}

Earnings per share is a significant performance measure that calculates the amount of profit that is attributable to each issued ordinary share of the company (Stainbank, Oakes, Razak, 2014). The importance of this ratio stems from the fact that investors are more interested in knowing how efficiently their individual share in the company has been utilized in generating profits, rather than merely having an overview of the total profits achieved by the entity (Stainbank, Oakes, Razak, 2014).

The 34.01 percent increase in basic earnings per share experienced by Pioneer Foods over the year puts it in a favorable position in relation to Tiger Brands and RCL Foods, whose basic earnings per share have decreased by 21.08 percent and 1115.56 percent, respectively. Although Tiger Brands and RCL Foods have experienced an increase in the number of ordinary shares in issue, earnings have evidently failed to compensate for that increase.

Diluted earnings per share indicates the lowest possible earnings per share, assuming that potential shares currently in existence are converted into 
ordinary shares (Service, 2014). Diluted earnings per share for Pioneer Foods increased by 30.99 percent from 2013 to 2014. This increase shows growth in the company, as there was an increase in the number of weighted average shares for the year. Tiger Brands and RCL Foods have experienced decreases, respectively, of 21.05 percent and 938.64 percent, which is only slightly lower than their respective basic earnings per share.

It should be borne in mind that the basic earnings per share calculation may be extremely volatile, as it includes all items of income and expenses, including abnormal items that do not regularly occur. This volatility is compensated for by the calculation of headline earnings, which more accurately represents maintainable earnings of the entity (Service, 2014).

Headline earnings per share is a JSE listing disclosure requirement intended to calculate earnings, as they relate to core trading activities of the company (Stainbank et al., 2014). Headline earnings per share for Pioneer Foods increased by 36.63 percent for the year, compared with decreases for Tiger Brands and RCL Foods, respectively, of 14.62 percent and 1093.75 percent.

Based on this analysis, it becomes evident that Pioneer Foods has made an overall improvement in terms of trading performance and earnings per share from 2013 to 2014. Although Tiger Brands has experienced a decrease in basic earnings per share, there has been an increase in headline earnings, which is a positive indicator for shareholders. RCL Foods, on the other hand, has performed unfavorably for the reporting period, which is mainly attributable to the fact that they failed to generate enough returns to compensate for the substantial increase in the number of ordinary shares that occurred during the year. This being the case, they have experienced a substantial decline in the earnings per share.

The market value ratios give clear evidence that choice of investment is between Tiger Brands and Pioneer Foods, as RCL Foods has performed poorly on the market and rendered negative returns for shareholders. The performance of Tiger Brands and Pioneer Foods can be interpreted in different ways. Some investors may prefer to invest with Tiger Brands, because they have exhibited a higher earnings and dividend yield. Pioneer Foods, on the other hand, has a higher EPS and has shown evidence of high growth potential, which some investors may prefer - particularly, if they are interested in long-term investment and growth. Lastly, there needs to be consideration for other qualitative and market related factors that can help investors to compare and contrast the two companies other than ratio analysis.

\section{Share price analysis}

5.1. The industry. The consumer goods industry in which Pioneer Foods and its competitors are located is an extremely volatile market characterized by virtually continuous and inevitable change and uncertainty. Most consumers, regardless of price increases, still need to purchase the staple consumer goods that they require on a daily basis (Alsemgeest et al., 2014).

One significant measure of a company's industry impact is its market cap, which is the total market value of the company's outstanding shares in rand value, calculated by multiplying the total number of outstanding shares by the current market price of the share (Investopedia, 2015). Of the three companies under discussion, Tiger Brands has the largest market cap (R52 billion), followed by Pioneer Foods (R42 billion) and RCL Foods (R16 billion).

5.2. Month-to-month share price. Refer below for the share price graph (Figure 1).

Over the five years leading up to 30 June 2015, Pioneer Foods has been at frontier of growth in the industry. In comparison with Tiger Brands and RCL Foods, Pioneer Foods' share price grew by 349.6 percent in this time period, while the corresponding growth for Tiger Brands and RCL Foods was, respectively, 62.54 percent and 6.75 percent (Moneyweb, 2015).

In the period 1 January 2015 to 30 June 2015, Pioneer Foods' share price showed a positive appreciation of 28.03 percent, while share prices for Tiger Brands and RCL Foods declined by 25.14 percent and 11.5 percent, respectively. This is mainly attributable to the fact that Pioneer Foods does not deal in poultry. Tiger Brands and RCL, on the other hand, both have interests in the poultry industry, which is under severe strain after passing of the AGOA (African Growth and Opportunity Act) agreement allowing the United States to export 650000 tons of chicken into the South African market and leading investors to be wary of potential saturation of the chicken market (News 24, 2015).

In a sign of growing investor confidence in the new board of directors, Pioneer Foods closed the second quarter (months ending 31 March 2014) favorably with a share price of $\mathrm{R} 83.50$ per share. The share price rose substantially over the remainder of the year, reaching a financial year high of R128.07 on 3 September 2014, before closing the year strongly on R118.00 per share, a 48.89 percent increase in share price from 24 February 2014. 
Although the appointment of a new board of directors had a positive effect on the share price during the 2014 financial year, the true effect of the appointment is seen more clearly during the 2015 financial year, when the share price grew even further, with the company expanding both locally and internationally.

It is evident that investor confidence increased in Pioneer Foods. Overall, the stock market reacted favorably to the decisions made by the company's board of directors and to external, macro and global factors affecting the company (Business Day, 2012). This, in the opinion of Moneyweb analysts, it was due to the fact that the company implemented valueenhancing initiatives focused on cost reduction and efficiencies which were expected to continued riving the group's earnings (Moneyweb, 2015). What is certain is that the company had shown considerable growth, and there was no evidence to suggest that this growth might stop.

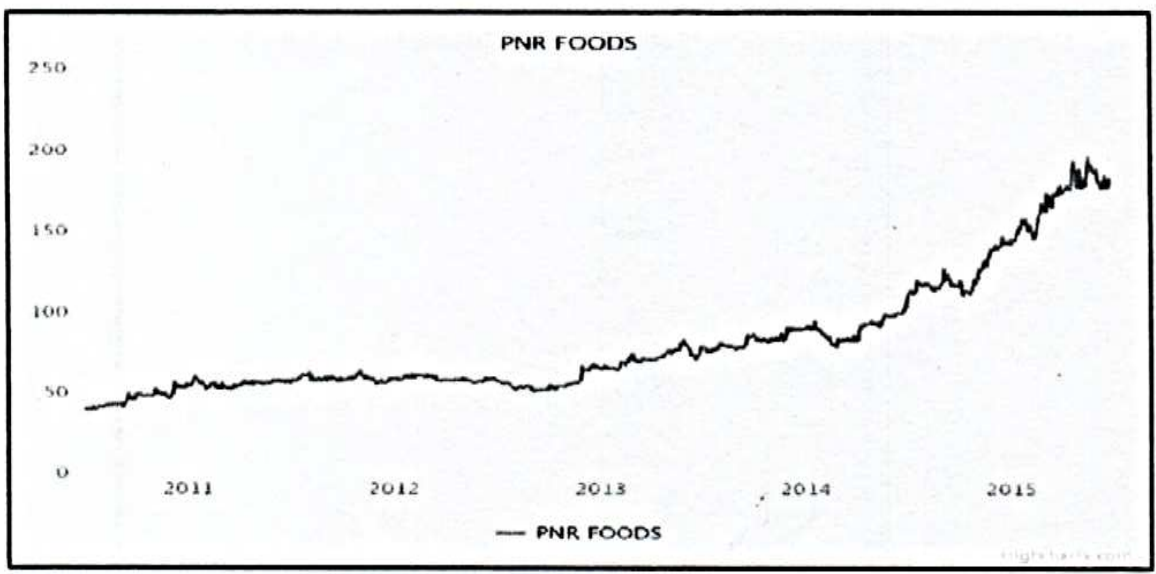

Pioneer Foods

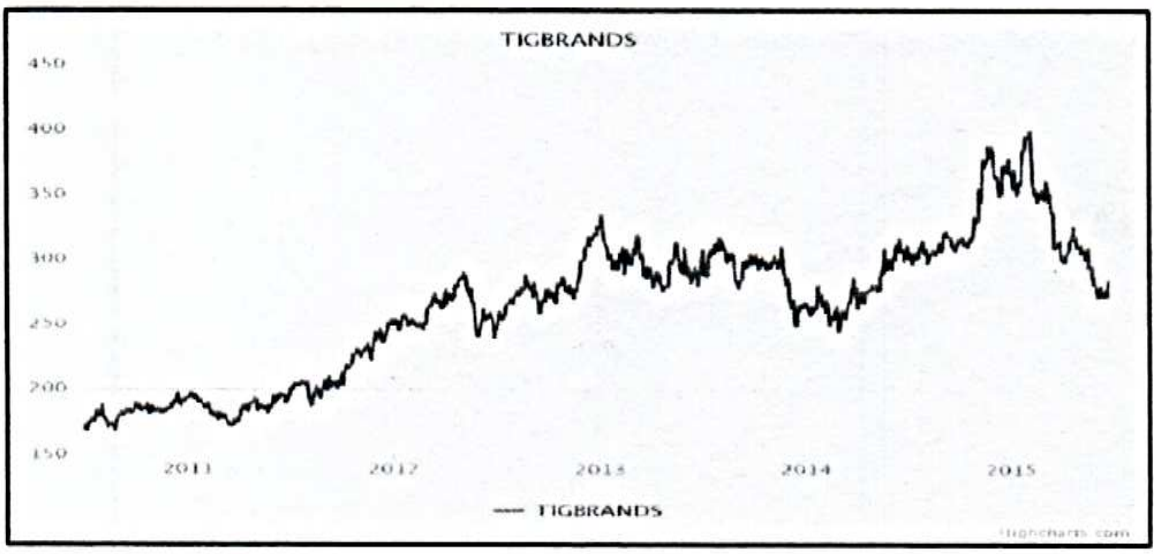

Tiger Brands

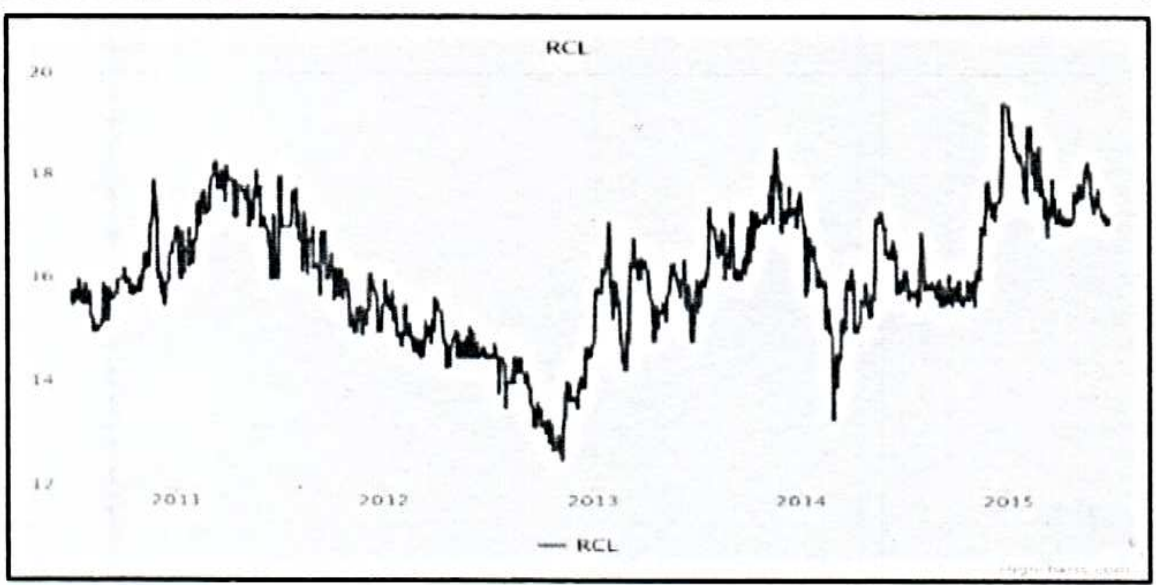

RCL Foods

Source: Moneyweb Click-a-company, 2015.

Fig. 3. Share prices of Pioneer Foods, Tiger Brands and RCL Foods 2011-2015 


\section{Summary and conclusions}

Invest in Pioneer Foods or not?

Deciding whether to invest in Pioneer Foods is not a simple matter of yes or no. There are pros and cons which have a greater or lesser effect on investors according to whether they are risk averse, or risk seeking. To arrive at an impartial conclusion, both the positives and the negatives must be considered in comparison with the company's main competitor, Tiger Brands.

\section{The cons:}

- In the DuPont analysis, Pioneer Foods' return on equity is 14.93 percent, 0.4 percent lower than that of Tiger Brands (15.33 percent). Tiger Brands' performance can be attributed to the higher profit margin of 6.62 percent compared to Pioneer Foods' profit margin of 5.35 percent. Pioneer Foods is leveraged higher than Tiger Brands by only 0.01 times. This indicates that they make similar use of leverage, yet Tiger Brands is more profitable. This DuPont analysis, thus, shows that Tiger Brands would be more beneficial to invest in, compared to Pioneer Foods.

- Pioneer Foods' debt-equity ratio is 0.48:1, whereas the figure for Tiger Brands is $0.44: 1$. This will be discouraging to the shareholder, as it means Pioneer Foods has less in total assets to pay off its total liabilities.

- Tiger Brands has a higher return on shareholder's equity than Pioneer Foods, as for every R1.00 investment in Tiger Brands ordinary shareholders receive a return of R15.33, compared to a return of R14. 93 from Pioneer Foods.

- Dividend yield ratio for Pioneer Foods shareholders is 1.11 percent lower than for Tiger Brands. This indicates that Tiger Brands is likely to be more favorable in the eyes of investors, as shareholders receive a higher return on the price that they have paid to invest in Tiger Brands.

- The earnings yield achieved by Pioneer Foods is 0.88 percent lower than the figure for Tiger Brands (5.76 percent). A higher percentage of earnings is being retained by Pioneer Foods for future reinvestment, which may not discourage investors, as their long-term weal this being considered, although this is a concern for the majority of short-term investors.

\section{The pros:}

- Profit for the year increased by R466.6 million from R498.6 million in 2013 to R965.2 million in 2014. Net cash generated from operations also increased from R1429.1 million in 2013 to
R2153.6 million in 2014. Because of this, Pioneer Foods increased operating cash flow/turnover ratio from 2013 to 2014; Tiger Brands, on the other hand, had a reduced operating cash flow/turnover ratio. This reduction in operating cash flow/turnover ratio for the rest of the industry indicates that the increase in operating cash flow/turnover ratio for Pioneer Foods is most certainly a positive sign for the investor.

- Pioneer Foods free cash flow increased from R368 million to R1 281.2 million, which is a 248 percent increase, which is most certainly a positive sign the investor. Tiger Brands' free cash flow as decreased from 2013 to 2014, yet is still double that of Pioneer Foods.

- Pioneer Foods' current ratio for 2014 is 1.38:1, which is $0.24: 1$ greater than the current ratio for Tiger Brands (1.14:1). This indicates that Pioneer Foods is more liquid than the industry, in regard to current ratio.

- For the 2014 year, Pioneer Foods (54.06 days) had a working capital cycle 41.12 days shorter than that of Tiger Brands ( 95.18 days). From an analysis of the asset management ratios, we can conclude that there is a favorable trend in efficiency of asset utilization by Pioneer Foods. This is a positive indicator for both existing and prospective investors, particularly, if the trend continues.

- Despite the decrease in the Pioneer Foods P/E ratio from 2013 to 2014, investors were still willing to pay more per rand of reported profits for Pioneer Foods than for Tiger Brands. Tiger Brands $\mathrm{P} / \mathrm{E}$ ratio was 17.37 times, which is 3.14 times lower than that of Pioneer Foods (20.51 times).

- The investor would be satisfied that a constant dividend pay-out has been paid (last nine out of ten years). Dividends per share increased from 132 cents in 2013 to 211 cents in 2014.

- Pioneer Foods experienced a 34.01 percent increase in basic earnings per share over the year, which placed it in a favorable position in relation to Tiger Brands (which showed a decrease of 21.08 percent). Headline earnings (a more stable indicator) increased for both Pioneer Foods (36.63 percent) and Tiger Brands (14.62 percent).

- During the period of 1 October 2011 to 30 September 2014, the Pioneer Foods' share price, rose by 349.6 percent, while the Tiger Brands share price grew by only 62.54 percent. During the more recent period of 1 January 2015 to 30 June 2015, Pioneer Foods' share price showed a positive appreciation of 28.03 percent, compared with a 25.14 percent decline for Tiger Brands. This was due to the fact that the company 
implemented value-enhancing initiatives (unbundled Quantum Foods in 2013, acquired Future Life and a Nigerian company, and appointed a new board of directors) focused on cost reduction and efficiencies which were expected to continue driving the group's earnings (Moneyweb, 2015).

Taking into account all the above-listed considerations, long-term investors should invest in Pioneer Foods, as the pros of the continuously increasing share price attributable to growth initiatives coupled with the impact of the new board of directors outweigh the cons of a lower dividend and return on shareholders' equity, compared to Tiger Brands. What is certain is that the company has had considerable growth and there is little evidence to suggest that this growth may stop in the near future.

It should, none the less, be noted that short-term investors would prefer an investment in Tiger Brands, as they would be receiving higher returns immediately.

This paper presents an exemplar of the DuPont system of financial analysis as applied to the top three firms in the South African food industry.

\section{References}

1. Accounting Coach. (2015). What is the statement of financial position? Available at: http://www.accounting coach.com/blog/what-is-the-statement-of-financial-position.

2. Alsemgeest, L., DuToit, E., Ngwenya, S. and Thomas, K. (2014). Corporate Finance: a South African Perspective. (G. Els, P. Alsemgeest, \& S. Viviers, Eds.). Cape Town: Oxford University Press.

3. Agala, S.R., Jadhav, P.K.D. and Borhade, S. (2014). A significance of financial ratio analysis in decision making: A case study of Kicons. Pvt. Ltd., Asian Journal of Multidisciplinary studies, 2 (10), pp. 205-211.

4. Bleby, M. (2010). Pioneer to pay R 500 million fine - cancels dividend. Available at: http://www.bdlive.co.za/ articles/2010/11/02/pioneer-to-pay-r500-million-fine---cancels-dividend.

5. Blessing, A. and Onoja, E.E. (2015). The role of financial statements on investments decision making: A case of United Bank of Africa PLC (2004-2013), European Journal of Business, Economics and Accountancy, 3 (2). Available at: http://www.idpublications.org.

6. Collier, H.W., McGowan, C.B. and Muhammad, J. (2006). Financial analysis of financial institutions in an involving environment. University of Wollongong. Faculty of Business Research Online. Available at: http://research-pubs@uow.edu.au.

7. Correia, C., Dillon, J., Flynn, O., Uliana, E. and Wormald, M. (2013). Financial Management. 8th Edition. Cape Town: Juta Publishing.

8. Demmer, M. (2015). Improving profitability forecasts with information on Earning Quality. School of Business and Economics. Discussion paper. Available at: http://www.diss.fu-berlin.de/docs/servlets/MCRFile NodeServlet/FUDOCS derivate 000000004923/discpaper2015 16.pdf

9. Fin24. (2015). SA Poultry producers shares fallon US chicken imports. Available at: http://www.news24. com/Archives/City-Press/SA-bans-import-of-poultry-products-20150429.

10. Firer, C., Ross, S.A., Westerfield, R.W., Jordan, B.D. (2004). Fundamentals of CorporateFinance. 3rd Edition. London: McGrawHill.

11. IFRS. (2013). A Guide through IFRS Part A. 2014 edition. London: IFRS Foundation.

12. Liesz, J.T. and Maranville, J.S. (2008). Ratio analysis featuring the DuPont method: an overlooked topic in the finance module of small business management and entrepreneurship courses, Small Business Institute Journal, Volume 1, pp. 17-34.

13. Investopedia. (2015a). Dividend Yield. Available at: http://www.investopedia.com/terms/d/dividendyield.asp.

14. Investopedia. (2015b). Market Capitalization. Available at: http://www.investopedia.com/terms $/ \mathrm{m} /$ marketcapitalization.asp.

15. Investopedia. (2015c). Price-Earnings Ratio. Available at: http://www.investopedia.com/terms/p/price-earnings ratio.asp.

16. Loth, R. (2015). Analyze Cash Flow The Easy Way. Available at: http://www.investopedia. com/articles/stocks/07/easycashflow.asp.

17. McClure, B. (2015a). Fundamental Analysis: The Balance Sheet. Available at: http://www. investopedia.com/university/fundamentalanalysis/fundanalysis7.asp.

18. McClure, B. (2015b). Fundamental Analysis: The Cash Flow Statement. Available at: http://www. investopedia.com/university/fundamentalanalysis/fundanalysis8.asp.

19. McGowan, C.B. and Stambaugh, A.R. (2012). Using disaggregated return on assets to conduct a financial analysis of a commercial bank using an extension of the DuPont system of financial analysis, Accounting and Finance Research, 1 (1) (online). Available at: http://www.sciedu.ca/afr.

20. Moneyweb. (2015a). Click-a-Company TBS. Available at: http://www.moneyweb.eo.za/tools-and-data/click-acompany/?shareCode=TBS.

21. Moneyweb. (2015b). Click-a-Company RCL. Available at: http://www.moneyweb.co.za/tools-and-data/click-acompany/?shareCode $=$ RCL.

22. Moneyweb. (2015c). Click-a-Company PFG. Available at: http://www.moneyweb.eo.za/tools-and-data/click-acompany/?shareCode $=$ PFG. 
23. Money-Zine. (2015). Analyzing the Balance Sheet. Available at: http://www.money-zine.com/ investing/investing/analyzing-the-balance-sheet/.

24. News 24. (2014). SA bans import of poultry products. Available at: http://www.news24.com/Archives/CityPress/SA-bans-import-of-poultry-products-20150429.

25. News 24. Pioneer Foods to acquire 50 percent of Future life Health Products. Available at: http://www.fin24.com/Companies/Retail/Pioneer-Foods-to-buy-50-of-Futurelife-20150423.

26. Onu, E. (2015). Pioneer Foods eyes Nigeria and beyond. Available at: http://www.bdlive.co.za/ business/retail/2015/03/20/Pioneer-foods-eyes-nigeria-and-beyond.

27. Penn State. (2015). Balance Sheet Analysis. Available at: http://extension.psu.edu/courses/meat-goat/financiaIinformation/farm-business-analysis/balance-sheet-analysis/.

28. Pioneer Foods. (2015). Annual Reports. Available at: http://www.Pioneerfoods.co.za.

29. Pioneer Foods. (2014). Annual Financial Statements. Available at: http://www.Pioneerfoods.co.za.

30. Reuters. (2015). Pioneer Food Group Ltd agrees to invest in Food Concepts Pioneer Limited. Available at: http://www.reuters.com/finance/stocks/PFGJ.J/key developments/article/3165047.

31. Rogova, E. (2014). DuPont analysis of the efficiency and investment appeal of Russian oil-extracting companies. 8th International Scientific Conference. Business and Management. Vilnius, Lituania. Available at: http://www.bm.vgtu.lt.

32. Service, C.L. (2014). Gripping Gaap. $15^{\text {th }}$ Edition. Durban: Lexis Nexis.

33. Sharma, R. (2012). Comparing and analyzing financial statements to make investment decision: Case study of Automotive Industry. University of Applied Sciences. Business Economics and Tourism. Available at: https://www.theseus.fi/bitstream/handle/10024/43723/SHARMA_RAJU.pdf?sequence=1.

34. Sheela, C.S. and Karthikeyan, K. (2012). Financial performance of Pharmaceutical Industry in India using DuPont Analysis, European Journal of Business and Management, 4 (14). Available at: http://www.iiste.org.

35. Soliman, M.T. (2008). The use of DuPont analysis by market participants, The Accounting Review, 83 (3), pp. 823-853.

36. Stainbank, L., Oakes, D., Razak, M. (2014). A Student's Guide to International Financial Reporting. $9^{\text {th }}$ Edition. Eston, South Africa: S\&O Publishing. 


\section{Appendix A: DuPont analysis}

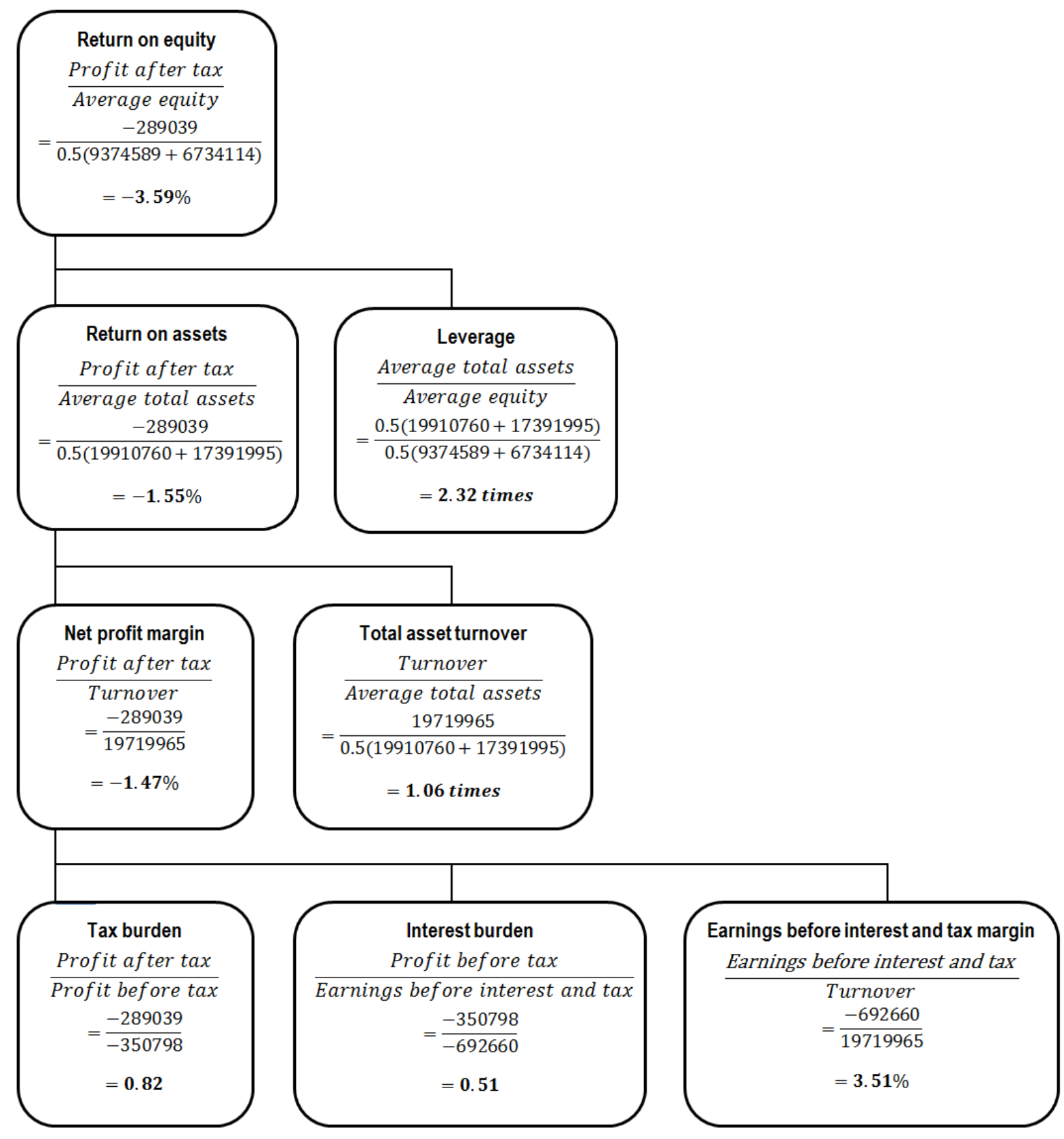

Fig. 2. DuPont analysis: RCL Foods 


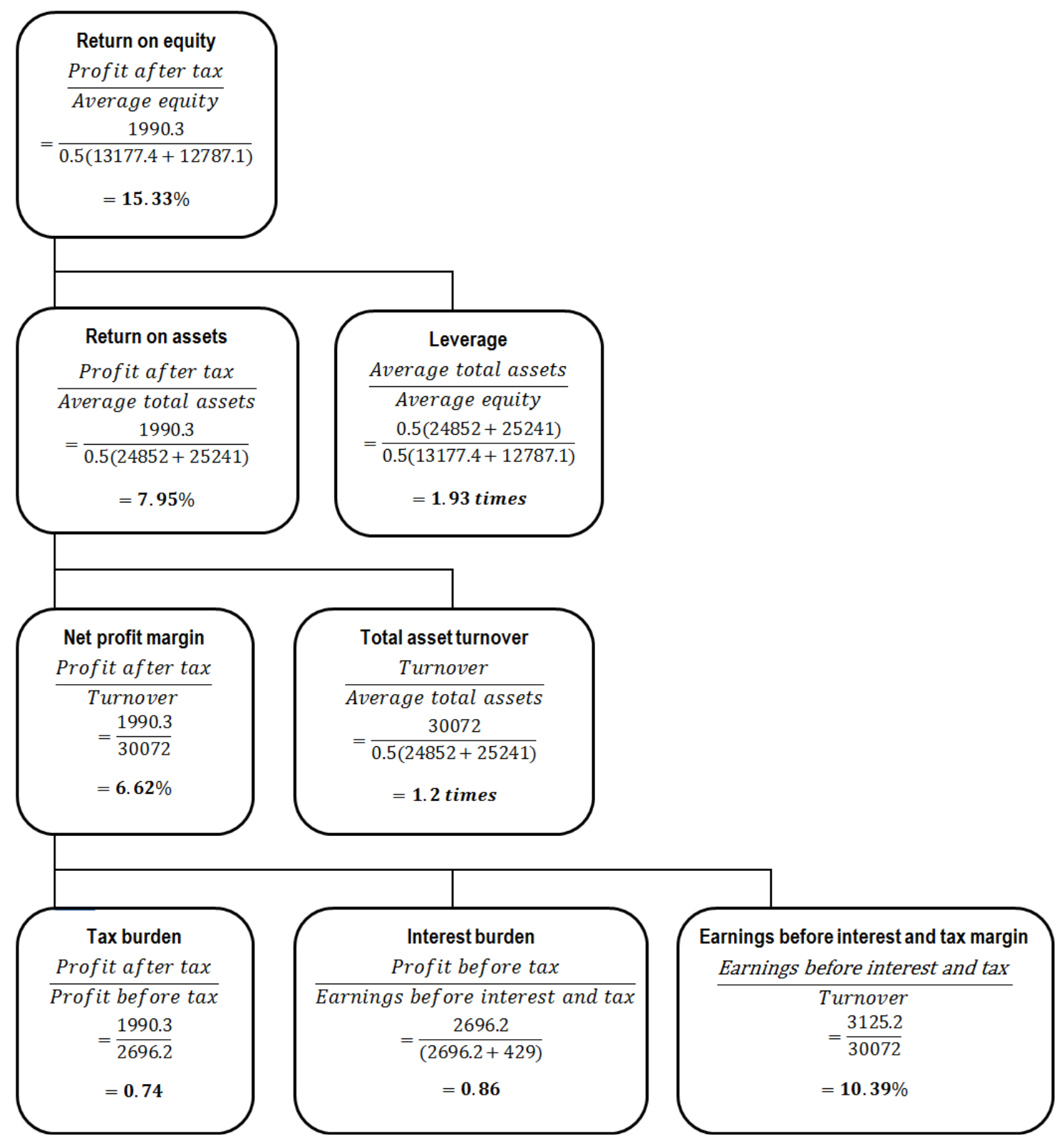

Fig. 3. DuPont analysis: Tiger Brands 


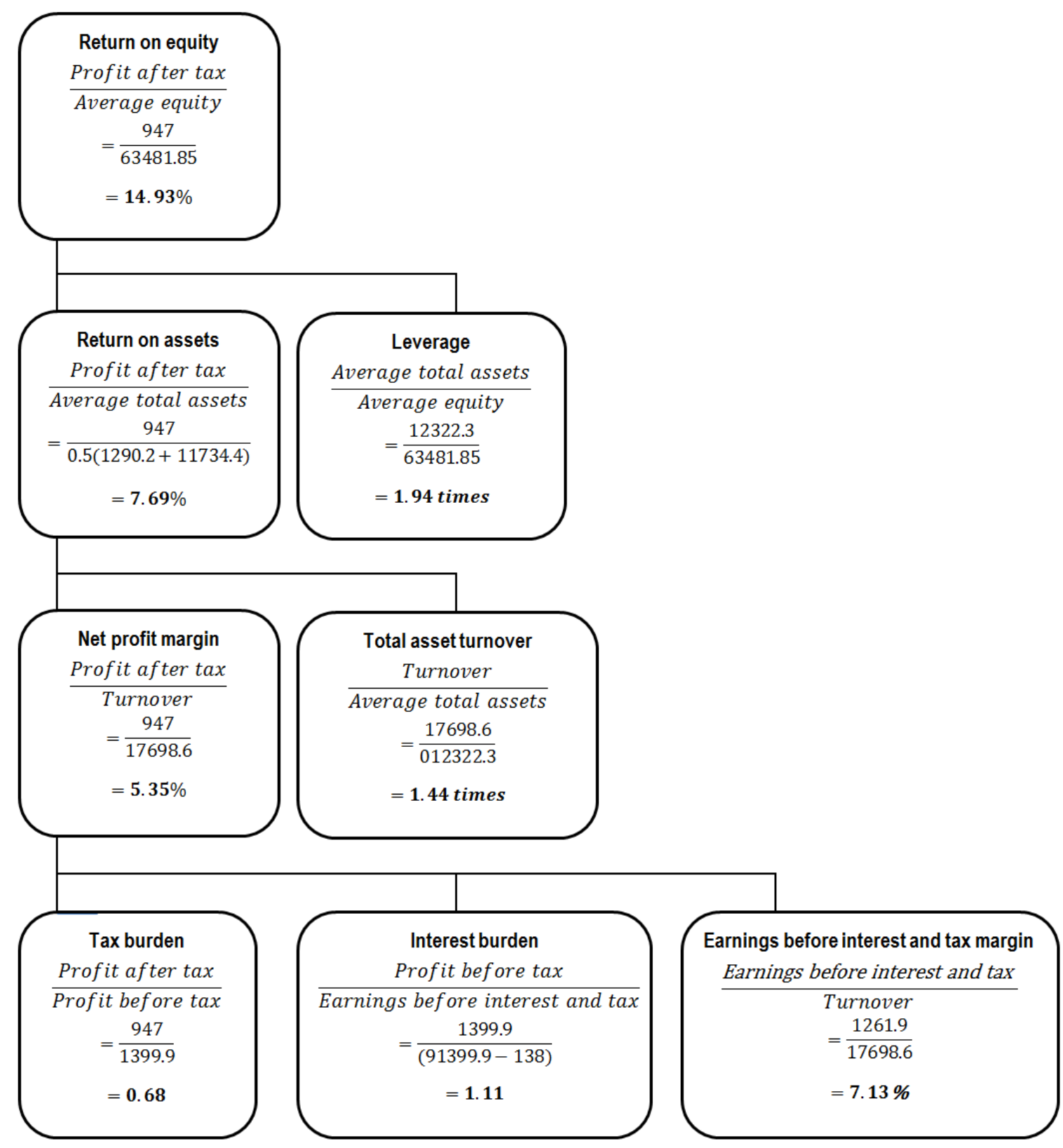

Fig. 4. DuPont analysis: Pioneer Foods 